\title{
De Gepredikte Jezus - De Prediking aangaande Jezus Christus tussen Theologie en Historie
}

Rein Bos ${ }^{*}$

(Universiteit Kampen, Nederlandmacht)

\begin{abstract}
The preached Jesus - The preaching of Jesus between theology and historism
\end{abstract}

This article deals with the tension between the preaching of the gospel of Jesus (the preached Jesus) as a source of joy on the one hand and the critical questions of the theologian (the historical Jesus) on the other. In this field of tension the question arises: who Jesus is to us at this point in time. The author deals briefly with these two approaches. He pleads for caution against a rigorous confessional or doctrinal approach on the one hand and on the other an approach in terms of which only the historically founded may be stated. The author searches for a way where justice is done to the view that in Jesus we are confronted with the world of God, but where historical criticism is also taken seriously. In this quest Barth and Marquardt are used as partners in dialogue. The admission that the Spirit creates a bridge between God and man, guards preaching against petrification and opens the way to meaningful creativity. The author accepts that preaching in itself provides no answer, but creates a space in which Christ himself may enter to speak. This presupposition prevents an arrogant theology. The preacher and congregation pray that the Spirit of God enters this space to speak. It does not result in vague content, but leads the preacher to speak in a careful and humble way on Christ. The space is guarded by the diligent scanning of the witnesses regarding Jesus and by anchoring them in the books of Moses, the prophets and David. Through this testimony God enters into our midst.

\subsection{Inleiding}

"Wie is Christus op dit ogenblik voor ons eigenlijk?" was de vraag van Bonhoeffer (1989:233-234). Het is een vraag die de geloofsgemeenschap vanaf haar begin heeft begeleid en dat zal blijven doen. Bij de beantwoording van deze vraag zegt de predikant op de kansel: "Vandaag mag ik u het evangelie van Jezus Christus verkondigen, bron van grote vreugde en blijdschap”. De theoloog slaat hetzelfde evangelie op en zegt: "Vandaag moet ik u confronteren met een groot probleem" (Den Heyer

\footnotetext{
* Lid van Homlit, Departement Praktiese Teologie, Universiteit van Pretoria.
} 
1990:9). Wanneer de predikant en de theoloog in één persoon verbonden zijn, ontstaat er spanning. De discussie over de christologie laat niemand in de geloofsgemeenschap onberoerd. Zo hebben in de voorbije jaren verschillende publicaties onrust onder gemeenteleden teweeg gebracht. Maar ook de prediker zelf blijft ook niet onaangeroerd door de resultaten van het moderne bijbelonderzoek. De theoloog in hem heeft geleerd kritische vragen te stellen. Als voorbeeld verwijzen we naar het debat over wonderen. "Preachers today are properly agnostic with respect to whether or not the biblical miracles occurred as described, for there is no way for contemporary research to confirm or deny the occurrence of such events. Today's hearers, however, are often concerned about these matters". In dat spanningsveld is de predikant geroepen om te (s)preken. Wat kan, mag en moet hij wel of juist niet zeggen? Derhalve klinkt de vraag: "Wie is Christus op dit ogenblik voor ons eigenlijk?”

\subsection{De historische Jezus}

De discussie rond de christologie trekt haar sporen in de prediking. Welke beelden van Jezus zijn daar aan te treffen? In verband met de ruimte van dit artikel spitsen we het vervolg toe op het dilemma tussen de "historische Jezus" en de "gepredikte Christus". Niet alle christologische ontwerpen zijn onder deze twee kopjes onder te brengen maar in verband met de beschikbare ruimte beperken we ons tot deze twee.

In de eerste plaats is daar de stroming die van mening is dat we over Jezus in de prediking niet meer kunnen en mogen zeggen dan historisch te verifiëren is. Daar heeft het historisch onderzoek een belangrijke plaats. En voor "zorgvuldige geschiedschrijving is voor bovennatuurlijk inbreuken op de gang der dingen in deze wereld principieel geen plaats" (De Jonge 1989:32; 1997:446). In deze beweging kunnen we de recente publicaties van o.a. De Jonge (1989:31-50; 1997:446-456; 1998:9-20; 1998:63-90), Kuitert (1998) en Den Heyer (1986:49-58) onder brengen. Bijbelse personen, bewegingen en gebeurtenissen worden niet verklaard vanuit een confessioneel of dogmatisch kader maar ze zijn object van historisch onderzoek waarbij gebruik gemaakt wordt van moderne middelen en methoden. Het gaat om de prediking van de "historische Jezus" en niet om wat de volgelingen daar later van gemaakt hebben met hun "gepredikte Christus".

Een positief gevolg van deze aandacht is dat er een opruiming plaatsvindt van aangroeisels en ongezonde vormen van jesulatrie. De keerzijde voor de praktijk van de prediking is dat er een wel zeer rigoureuze opruiming plaatsvindt waardoor er van Jezus niets anders of meer overblijft 
dan een "Joodse man uit het jaar nul". In de praktijk der prediking is er voor Jezus de rol van moreel voorbeeld. We kunnen denken aan een zin uit Gezang 172 van het Nederlandse Liedboek voor de kerken waar de gemeente zingt: "Een mens te zijn op aarde, is net als Jezus worden die 't ons heeft voorgedaan”. Een andere rol die Jezus kan worden toebedeeld is die van wijsheidsleraar, al of niet in gnostische zin, in klassieke of modieuze New-Age gedaante.

Binnen dit “Anliegen” vormen de evangeliën de primaire bron voor de preken (Kuitert 1998:73). Een gevolg daarvan is weer dat preken nauwelijks of geen gebruik maken van de christologische "Hohheitstitel" (Hahn, 1963) zoals die in de apostolische literatuur zijn te vinden. Die worden binnen het historisch-kritisch onderzoek gerekend tot de latere aangroeisels van de gemeente theologie. Daarom worden deze met de nodige voorzichtigheid en zelfs scepsis behandeld. De hedendaagse prediking over Jezus zoekt in deze stroom zo dicht mogelijk aansluiting bij de oorspronkelijke prediking van Jezus (De Jonge 1998:9-20; Campbell 1997).

\subsection{De gepredikte Christus}

Een andere beweging gaat er van uit dat de evangeliën zijn geschreven door de volgelingen die diep onder de indruk waren gekomen van de ervaring van Pasen. Van daaruit kijken apostelen en evangelisten terug op de ervaringen met en herinneringen aan Jezus van Nazareth. De compositie van dat materiaal is niet primair gebeurd om een voor ons besef gedetailleerd historisch verslag te geven maar om te getuigen dat Jezus de Christus is. Derhalve staat in deze beweging niet de historische Jezus maar de verkondigde Christus in het centrum. Binnen deze beweging zijn twee contraire stromen te onderscheiden. Allereerst is daar het klassiek heilshistorische kader. Daarin is Jezus de beloofde Messias waarvan Mozes en de profeten reeds spreken.

Jezus is gekomen om Gods oordeel over de zonde te dragen en zijn genade voor zondaren te openbaren. Door zijn dood is de menselijke schuld verzoend. En een ieder die in Hem gelooft zal niet verloren gaan maar eeuwig leven hebben. Dit paradigma kan zowel naar aanleiding van oudtestamentische (Greidanus, 1999) als van nieuwtestamentische teksten worden gehanteerd. Vanuit theologische overwegingen gaat men uit van de historiciteit van de gebeurtenissen en de betrouwbaarheid van de nieuwtestamentische getuigen; de evangeliën bieden geen verhalen maar geschiedenissen. Voor de praktijk betekent dit dat de inhoud van de 
prediking haar volle theologische en existentiële gewicht krijgt. De hoorders wordt heil en redding aangezegd die God in Jezus Christus heeft bewerkt.

De keerzijde van dit theologisch paradigma voor de prediking is, dat Jezus een gestalte uit het verleden is. Om in de prediking de betekenis voor vandaag aan te duiden, moet de prediker een applicatieve constructie maken of bedenken. Een andere schaduwkant van deze benadering is dat een preek, naar aanleiding van elke mogelijke tekst, een soort vast heilshistorische patroon gaat bevatten waardoor opbouw en inhoud van de toepassing erg voorspelbaar worden. Een egalisering van de veelvormigheid en veelkleurigheid van de Schrift ligt dan op de loer.

Een tweede stroom binnen deze tweede beweging is die waarbij het historisch onderzoek totaal buiten haakjes wordt gezet en irrelevant verklaard voor de prediking. Teksten, beelden en voorstellingen worden ontdaan van hun mythologische gewaad om de "eigenlijke" kern over te houden. We kunnen hierbij denken aan recente publicaties van Drewermann en van Ter Linden. Deze lijn bood voor de prediking de mogelijkheid om relaties te leggen met verhalen uit het hier en nu. Er kunnen verbindingen worden gemaakt met ervaringen in het pastoraat en de inzichten van de pastorale psychologie. De keerzijde is dat voor Jezus in de prediking uiteindelijk alleen de rol van therapeut overbleef die de weg uit de angsten voor dood en leven wijst of een weg om met die angsten om te gaan. Jezus is binnen dit concept niet de brenger van verlossing en heil; Hij wijst een weg waarop mensen zichzelf moeten redden.

In dit artikel willen wij bouwstenen aandragen voor een weg waarbij enerzijds recht gedaan wordt aan de weerbarstigheid van de uitspraak dat we in Jezus met de wereld van God worden geconfronteerd zonder dat we daarmee op voorhand allerlei dogmatische en confessionele terminologie overnemen. Aan de andere kant willen we het historisch onderzoek serieus nemen zonder ons tot het minimalistische "Jezus was een Joodse man uit het jaar nul" te reduceren. Daarbij zoeken we geen weg tussen twee uitersten in maar we zoeken een weg waarop recht wordt gedaan aan de bijdragen van historie en kerygma. Mogelijk komen op die weg de kansel en de katheder in elkaars blikveld. Op onze zoektocht in dit artikel zijn Barth en Marquardt onze gesprekspartners.

\section{BARTH EN MARQUARDT}

\subsection{De werelden van Barth en Marquardt}

Barth theologiseert na de Eerste Wereldoorlog. Alles is in beroering en op allerlei gebied worden nieuwe wegen gezocht en uitgeprobeerd. In de wijsbegeerte komt Heidegger met Sein und Zeit'. Ook en met name in de 
kunsten treden juist in die vroege jaren 20 enorme verschuivingen op. Te denken is aan de werken van Joyce, Svevo, Mann om maar enkele bekende namen te noemen. In de muziek neemt de tweede Weense school het voortouw, de naam Schönberg spreekt hier voor zichzelf. En wat te zeggen van de schilderkunst waar Picasso, Malevich, Mondriaan en vele anderen op nieuwe wijze naar de wereld kijken en hun ervaringen tonen. Wanneer in het geheel van de cultuur zulke ingrijpende wijzigingen plaatsvinden doet de theologie ook mee.

Marquardt theologiseert in de schaduw van de Tweede Wereldoorlog en op de rand van de Koude Oorlog en daarna. Op de puinhopen van een verwoest werelddeel moeten samenlevingen opnieuw gebouwd worden. In West Europa valt alle nadruk op herstel en wederopbouw. Tegelijk zijn daar de talloze herinneringen aan het grote kwaad. Hoe gaan mensen om met een verleden dat zoveel wonden kent en zo diep beschadigd is. Niet alleen wederopbouw is aan de orde van de dag. Het naoorlogse existentialisme verslaat zijn tienduizenden. In alle hevigheid komt de absurditeit van het bestaan in vele kunstwerken naar voren. Men denke aan de enorme invloed van de werken van Camus. Maar ook zoeken beeldend kunstenaars naar nieuwe vormen om expressie te geven aan hun beleving van de werkelijkheid. De Cobrabeweging is hier een buitengewoon boeiend teken van. In de jaren 60 van de 20e eeuw komen we een sterke hang naar vrijheid tegen. De theologieën van de genitief doen hun intrede. Het beeld schijnt er rooskleurig uit te zien. Een theologie van de bevrijding en van de hoop houdt velen in de ban, terwijl in het verre Azië bittere oorlogen worden uitgevochten en door Europa een ijzeren gordijn loopt. Wij denken dat de belangrijkste theologische bezinning van de 2e helft van de 20e eeuw gelegen is in de wending naar het Jodendom. In de bezinning op de Joodse wortels van het Nieuwe Testament en in het gesprek met de synagoge vallen de echte beslissingen. Het is Marquardt die deze bezinning recht wil doen in zijn vernieuwende systematische theologie. Des te indringender is de vraag "Wie is Christus op dit ogenblik voor ons eigenlijk?".

\subsection{Barth}

Op zoek naar een antwoord is Karl Barth onze eerste gesprekspartner. Hij stelde op evidente wijze de vraag naar God en daarmee impliciet de vraag naar de betekenis van Christus aan de orde. "Wer 'Jesus Christus' sagt, der darf nicht sagen: 'es könnte sein', sondern: es ist. Aber wer von uns ist in der Lage 'Jesus Christus' zu sagen?”. En dit vanuit de grondervaring dat het onmogelijk is zuiver over God en Jezus Christus te spreken terwijl er 
niettemin de opdracht ligt om dat te doen. De spanning tussen deze twee polen werkt door in zijn gehele oeuvre.

Het is ongetwijfeld zo dat deze ervaring bij Barth te maken heeft met de maatschappelijke en culturele situatie waarin hij verkeerde. Niet alleen de wending in al het theologisch bezig zijn ten gevolge van de eerste wereldoorlog is hier fundamenteel. Ook de ervaring van het gebrek aan werkelijke communicatie binnen het geheel van de werkelijkheid speelt hier mee. Hoe kunnen wij nog uitdrukken wat ons bezig houdt wanneer de middelen daarvoor niet meer toereikend zijn? Is er niet een "sprakeloosheid" die allen omgeeft?

Uit het brede en veelkleurige oeuvre van Barth, richten we in dit artikel de aandacht op een lezing van Barth voor predikanten uit 1922. De titel van de lezing is: "Not und Verheissung der christlichen Verkündigung" ([1922]1990b:65-97). Daarin stelt Barth indringend de vraag naar het spreken over God en de verlegenheid daarbij aan de orde. In de context van het verhaal gebruikt hij het woord verkondiging, dat begrip valt te omschrijven met "spreken over God". Hoe omlijnt Barth hier de mogelijkheid van het (s)preken over God en Jezus? Als het enerzijds de nood van de prediking is om over God te spreken terwijl dat eigenlijk niet mogelijk is, terwijl anderzijds het Woord Gods erop wacht open te gaan en als kracht het leven binnen te treden, dus als belofte, hoe is dan "het waagstuk der prediking” aan te gaan?

Barth begint met een tekening van wat er op zondagmorgen te zien en te horen valt wanneer een kerkdienst begint. Er is het geluid van klokken en er zijn mensen die naar een gebouw toekomen, er wordt gezongen en gebeden. Ogenschijnlijk een oude en eerbiedwaardige traditie. Barth duidt dit fenomeen als een gebeuren waar mensen iets van verwachten. Op één of andere manier komen de mensen voor iets naar dit gebouw toe. En er is dan ook een mens die aan deze verwachting gestalte geeft door het woord te nemen en te lezen uit de bijbel en te spreken over God. Wat is die verwachting eigenlijk waarin mensen op zoek gaan? Het boeiende is dat Barth hier de vraag stelt: "Ob’s denn auch wahr ist?"

Onder hun zoektocht ligt, vaak diep verborgen, de vraag naar een laatste zin en betekenis. Barth gaat op die vraag in door die te duiden als een vraag waarin de mens zelf in het geding is. Hij gebruikt dan ook het woord "end-geschichtlich" om aan te geven hoezeer in dit menselijk verlangen het eigen levensverhaal opnieuw bevraagd wordt. De situatie van de mens draagt in die zin een eigen ernst en gewicht met zich mee. Immers, de mens wordt door dit verlangen bewogen. Dat is de ene kant van de 
eerbiedwaardige traditie van de zondagmorgen. Er is ook een andere. Er is ook een verhaal, door Barth aangeduid met het woord bijbel, dat eveneens een verwachting indraagt in de situatie. De bijbel brengt in de situatie een antwoord, maar dan zo dat het verhaal op zoek is naar de vraag van de mens. Er is geen antwoord zonder vragende mensen. En dan stelt ook de bijbel de vraag “ob’s denn wahr ist”. Want het antwoord is allereerst een aanscherping en verdieping van de vraag van de mens. In het verhaal klinken immers de vragen in het licht van het spreken van God die het leven stelt onder de kritiek van het kruis. Dus een aanscherping, twijfel is twijfel aan God, lijden is lijden aan God.

Maar dan maakt Barth weer een beweging. Want zegt hij, wie deze kritiek ervaart kan dat alleen maar omdat er in de kritiek een ja-woord klinkt. Het kruis is niet te verstaan zonder de opstanding, het neen nooit zonder het ja. Met andere woorden; in de vragen van de mens ligt het antwoord verborgen. Dit lijkt een fraai spel van woorden, een heen en weer gaan van ja en nee, maar Barth laat de spanning van de dubbele verwachting staan wanneer hij stelt dat de bijbel vraagt naar mensen die deze ervaring toelaten. De vragen van de mens vormen een schaduw van de vraag die het verhaal stelt.

Wat er vervolgens gebeurt is dat Barth de twee verwachtingen op elkaar betrekt en daarbij als het ware ruimte uitspaart voor een werkelijk spreken dat hij afhankelijk stelt van Hem die in het verhaal betuigd wordt, God. Hij geeft voortdurend aan dat in de vragen van de mens de vraag naar het laatste meeklinkt. Ook wijst hij erop dat in de vraag van de mens een antwoord voorondersteld is, zoals in de toespitsing vanuit het verhaal evenzeer een antwoord klinkt. Maar in het feitelijk spreken van mensen over God kan geen sprake zijn van een vervulling, een voltooiing. Dat mensen in hun taal naar God pogen te verwijzen mag waar zijn, dat hun woorden Hem ook present stellen is een onmogelijkheid. Vandaar dat Barth verwijst naar de oud-kerkelijke hymne "Veni Creator Spiritus". Daar, in de zucht naar de Geest komt aan de orde dat mensen hooguit een vermoeden kunnen uitspreken naar dat wat hun denken en bezinnen overstijgt. Daarom kan gezegd worden dat Barth een ruimte uitspaart waarin een verwijzing plaatsvindt naar Hem die in het verhaal aan de orde komt. Meer niet, minder ook niet, een ruimte die eerst in de ervaring van de roep om de Geest wordt geduid als heilige grond. Dat God deze zucht rechtvaardigt is zijn geheimenis. 


\subsection{Marquardt}

In 1988 verscheen de Prolegomena van de dogmatiek van FriedrichWilhelm Marquardt, leerling van Karl Barth. Marquardt zoekt en tast naar een theologie die in structuur en inhoud bepaald wordt door de vragen die na de Tweede Wereldoorlog op het grensvlak van Jodendom en christendom worden gesteld. In 1990 en 1991 verschijnen de twee delen over de christologie. In het kader van dit artikel noemen we twee belangrijke elementen uit het tweede deel.

Een eerste punt van belang is dat Marquardt Israël de formele christologie noemt (1998:52-237). Dat wil zeggen dat woorden, beelden, voorstellingen die de apostelen en evangelisten hanteren om van Jezus te getuigen, niet pas na de geboorte van Christus zijn gesmeed maar deze zijn voorgegeven in het getuigenis van Mozes en de profeten; daar liggen de "Elementarteilchen" voor de christologie opgeslagen (1998:52,57). Elk christologische bezinning zal dan ook steeds weer terug moeten naar de wereld van deze "elementaire deeltjes".

Als tweede noemen we de bespreking door Marquardt van de christologische vragen zoals Mattheüs die overlevert. De eerste maal laat Johannes de Doper een vraag aan Jezus stellen: "Zijt Gij het die komen zou of verwachten wij een ander?" (Math 11:2-6). Jezus "gibt selbst keine christologische Antwort” Marquardt 1998:25). De vragensteller wordt voor een antwoord naar twee plekken verwezen: het horen van de Schriften en het zien van de werken van Jezus. En daarmee geeft Jezus de vraag aan de vragensteller terug en doet een beroep op zijn eigen oordeelsvermogen. Daarmee blijft de vraag open en ze moet, naar de mening van Marquardt, ook open blijven zolang God deze zelf niet heeft beantwoord. "In der ganzen Christologie geht es nicht um feste Behauptungen, sondern um ein Abwägen der Möglichkeiten, die Christusfrage als von Gott beantwortet zu verstehen. Der Gedanke, daß man statt auf Jesus auch noch auf einen ganz anderen zu warten hätte, begleitet die christologische Frage ständig: Sie ist die Anfechtung und damit die Grenze der Christologie” (Marquardt 1998:25). Daar laat Marquardt (1998:26-27) direct een bespreking op volgen van de tweede christologische vraag, die van Jezus aan zijn leerlingen (Math. 16:13-16). Na de vraag "Wie zeggen de mensen dat Ik ben?” Marquardt concludeert daar uit dat Jezus de mensen om hem heen in staat acht om de vraag te beantwoorden (1998:28). Die conclusie wordt versterkt wanneer we bedenken dat Jezus geen van de gegeven antwoorden expliciet afwijst. "Jesus läßt das stehen, sagt nichts dazu: nicht Ja, nicht Nein - er kommentiert nicht einmal; mag es im Volk so weiterwirken; auf 
christologische Exaktheit kommt es Jesus nicht an”. Jezus is vervolgens geïnteresseerd in het antwoord van de leerlingen zelf: "Wie zeggen júllie dat Ik ben?” Petrus geeft als antwoord: “Gij zijt de Christus de zoon van de levende God". Dat antwoord van Petrus is in credo en dogma van de christelijke kerk een prominente rol gaan spelen. Zelfs zozeer dat in de loop der tijd de oorspronkelijke vraag (van Jezus) achter het antwoord (van Petrus) is verdwenen. Marquardt voert een indringend pleidooi om het antwoord van Petrus niet als laatste te zien maar de dialectiek tussen vraag en antwoord dynamisch te houden. Deze dialectiek staat open totdat Hij komen zal om te oordelen de levenden en de doden (Marquardt 1998:337vv). Het is Jezus zelf die de christologische vraag oproept en tegelijk is Hij het die elke systematisering of vastlegging tegengaat.

Aan het einde van het tweede deel van de christologie komt Marquardt nog eens terug op het open karakter van de christologische vraag. Dan verscherpt hij dat door het Joodse Nee tegen Jezus van Nazareth in te brengen. De onverloste wereld is daar het grootste argument. "Christen müssen sich plagen lassen von der Anfechtung durch dieses jüdische Nein”. Dat Nee zegt christenen namelijk "daß Gott noch nicht am Ende ist”. Maar ook de gemeente is daardoor geroepen zich niet neer te leggen bij de status quo. In dat licht moet de bede "Maranatha" worden verstaan. Zolang de christologische vraag wacht op zijn laatste en definitieve beantwoording, ligt voor de volgelingen van Jezus Christus de weg van de concrete navolging open, de persoonlijke deelname aan de weg van Jezus van Nazareth. "Der Gegenstand der Christologie ist kein toter Gegenstand, sondern lebendiges, uns berührendes und fornderndes Dasein”.

\subsection{Het uitsparen van een ruimte}

We stellen Barth en Marquardt aan de orde omdat we bij beiden een manier van denken en formuleren tegenkomen die ons ieder op de eigen wijze kan helpen als het gaat om de vraag "Wie is Christus voor ons vandaag?” Barth biedt niet zozeer een oplossing voor de vraag hoe je op de rechte wijze over God en Christus kunt spreken. Dat is niet aan de orde, hij geeft veeleer een weg aan waarop mensen in hun denken en bezinning kunnen ervaren dat er momenten zijn waarop dit denken en bezinnen overstegen wordt. In de taal van Barth is die ervaring zoveel als de nood en de belofte van het spreken over God. Hoezeer de manier van spreken ook dialectisch is, de intentie van Barth is tenslotte om mensen bij het gebed om de komst van de Geest te brengen.

Vervolgens valt hier op hoe voorzichtig de formuleringen klinken. Het verschijnsel van de kerkdienst op de zondagmorgen is op zich zelf geen 
enkele garantie dat er ook een presentie te vieren valt. Integendeel, dat mensen komen en meedoen in de liturgie is zeker representatief voor hun vreugde en leed, voor hun zoeken en tasten, voor hun vraag naar wat er toe doet. Het is zelfs een teken van een vraag onder alle vragen, maar hier valt niets te tonen en mee te delen als vaststaand.

Het blijft een geheimenis wanneer de ruimte die de taal uitspaart, door het verhaal wordt ingevuld. Dat is nu een verstaan van het fenomeen kerkdienst waarin enerzijds recht gedaan wordt aan de feitelijkheid van het gebeuren en anderzijds aan het gegeven dat werkelijke communicatie een geheimenis is en blijft. Onder mensen maar dan ook tussen God en mens.

Marquardt scherpt dat naar ons besef nog verder aan doordat hij deze ruimte langs drie lijnen fundeert. In de eerste plaats verbind hij de ruimte in het christologisch belijden met het veelkleurige karakter van de getuigen bij Mozes en de profeten. Vervolgens laat Jezus zelf een ruimte open en nodigt Hij mensen uit die ruimte telkens opnieuw te vullen. In de derde plaats is die ruimte gegeven met de Joodse tegenspraak: zolang het Koninkrijk nog niet daar is, staat het christologisch credo onder een voorbehoud. Het uitsparen van ruimte in het spreken over God lijkt ons de essentie van de bezinning over de vraag of er in prediking en liturgie zoiets als werkelijke presentie kan zijn. Het geheimenis van Gods presentie is niet zoiets als een raadsel dat opgelost kan worden. De prediking heeft dit geheimenis te respecteren en de homiletiek moet dat geheimenis "methodisch behüten" (Grözinger 1995:158). Barth en Marquardt willen, ieder op hun eigen wijze, daartoe een weg wijzen in culturen en werelden waarin alles op z'n kop stond. Deze wegen doen recht aan de ervaring dat wij slechts in fragmenten denken en geloven maar tegelijk hebben zij in de crisis van de sprakeloosheid een verwoording van de christelijke traditie gegeven die weigert het grote verhaal van God en mens aan de kant de schuiven, als was het niet meer van belang.

\section{VERWERKING}

\subsection{Over de attitude van de prediker in het proces van preekvoorbereiding}

De huidige christologische discussie brengt zowel de gemeente als de prediker in verlegenheid. Deze verlegenheid mag geen nonchalante ignorantie zijn die bij gebrek aan inhoudelijkheid de christologische vragen overgeeft aan een leegte waarin alle katten grauw zijn. Dat kan niet de bedoeling zijn. Daarom vragen we in dit gedeelte naar de gevolgen van de benadering van Barth en Marquardt voor de attitude van de prediker wanneer deze zich zet aan de voorbereiding op de preek. Wie een preek 
voorbereidt start een intensief proces. Niet alleen worden teksten en contexten nauwkeurig bekeken en zo mogelijk geanalyseerd, ook een soms jarenlange pastorale ervaring en een staan in de hedendaagse cultuur, het speelt allemaal een bepalende rol. Door dit alles heen ontkomt de predikant niet aan het luisteren naar het eigen hart en naar de weerklank die het evangelieverhaal heeft in het eigen leven. Ook wat er aangaande de Christus wordt verkondigd is een uiting van wat men leest in de teksten en wat men door de jaren heen in de existentie van het eigen geloof heeft gewonnen of verloren. In die zin raken om zo te zeggen "de historische Jezus" en "de verkondigde Christus" aan elkaar. Maar dat is niet een vanzelfsprekend feit. Integendeel, de intenties die wij bij Barth en Marquardt bespeurden geven aan dat er voor de vraag "hoe te preken" een andere ligt "kan men eigenlijk wel preken”. Deze vraag willen we hier als een homiletische vooronderstelling duiden, niet als een aan de persoon van de predikant gebonden. Juist als het gaat om de betekenis van Christus is deze vraag van belang. Als de prediking voor het wonder van zijn presentie ruimte wil maken zonder die presentie op voorhand in te vullen dan wel achteraf te claimen, heeft dat gevolgen voor de wijze waarop de voorbereiding geschiedt. Wie ruimte wil scheppen zal eerst ruimte in zichzelf moeten vinden.

De vraag is waar de prediker die ruimte ontdekt, koestert en ontgint. In de grote spirituele tradities wijst men dan op de meditatie en het gebed. Daarin komen een paar centrale momenten naar voren. De stilte waarin de teksten klinken geeft de prediker heel basaal een ervaring waarin het wachten op Gods woord geoefend wordt. Hier krijgt de genoemde "verlegenheid" ook de kans om vruchtbaar te zijn voor de preek. De "verlegenheid" bepaalt de prediker bij zijn eigen onmacht en sprakeloosheid.

Naast het wachten op het Woord Gods is daar ook de omgang met datzelfde Woord waarop men wacht. Die omgang heeft het karakter van het gebed. Het is niet zonder reden dat Barth uitkomt bij het gebed om de Geest. Voor hem is dit niet een noodoplossing, het is geen excuus om de onmacht te maskeren. Het is wel de expressie van een verbijstering waarin het besef van het wonder doorklinkt. Voor Barth is het gebed altijd de kern van het theologisch reflecteren en denken geweest. In zijn afscheidscolleges heet het zo: "Rechte Theologie wird, indem sie bedenkt, dass Gott nur als handelndes und sprechendes Subjekt ihr Objekt sein kann, implizit und indirekt notwendig Proslogion, Suspirium und also Gebet sein. Alle liturgischen Bewegungen in der Kirche kommen zu spät, wenn nicht gerade 
ihre Theologie von ihrem Ansatz her liturgische Bewegung ist, in Proskynese ins Werk gesetzt wird".

De opmerking over de liturgische bewegingen voegen we toe omdat de preekvoorbereiding zich richt op wat in de liturgie van de gemeente aan de orde zal komen. Zowel het werk van de prediker als de liturgie van de gemeente staan hier in het teken van de "aanbidding". Ook de liturgie wordt door het gebed gedragen en heeft kennelijk geen bestand in zichzelf. Voor de liturg is de afhankelijkheid van het Aangezicht Gods primair.

Dit brengt ons bij een laatste karakteristiek van de attitude van de prediker. Wie in meditatie en gebed de preek voorbereidt zal zich waarschijnlijk herkennen in een opmerking van de "jonge" Barth die hij ooit deed in de beroemde rede van Tambach. Op de vraag "wat moeten wij doen?” geeft Barth (1922:69). het antwoord: “Wir können ja doch nur eines tun, nicht vieles. Und das Eine tun gerade nicht wir. Denn was kann der Christ in der Gesellschaft anders tun, als dem Tun Gottes aufmerksam zu folgen?" In de preekvoorbereiding wordt de prediker niet alleen geconfronteerd met de grote "verlegenheid" maar ontvangt ook de kans een spiritualiteit van de ootmoed te beoefenen. Juist als het gaat om de betekenis van Christus zijn hier de intenties van Barth en Marquardt ook van praktisch-theologisch belang in het homiletisch proces.

\subsection{De betekenis en inhoud van het homiletische "est"}

Wanneer we zeggen dat de prediking op een of andere wijze beoogt ruimte te maken voor God en zijn heil, wat dan te denken van de uitspraak van de Confessio Helvetica Posterior, "Praedicatio verbum Dei est". Wat is de aard van dit "est"? Is dat niet al te pretentieus? Dat kan het zeker worden wanneer de prediking meent "de Christus der Schriften" of ook "de historische Jezus" te verkondigen. Zowel de "historische Jezus" als de "Christus der Schriften" is immers altijd mee bepaald door het beeld dat wij van hem maken, c.q. gemaakt hebben. Is er van de prediking meer te verwachten dan deze beelden? Wij stellen voor het "est" te vullen vanuit de belofte dat God zich aan een menselijk poging wil verbinden. Het gaat immers steeds weer over de God die is, die was en komen zal. In deze zin en in de effectuering daarvan komt zijn trouw tot uiting. "Die Seinsweise Jesu von Nazareth is die eines ewig Kommenden”, zegt Marquardt (1998:321). Om enkele pagina's verder daar als het ware aan toe te voegen "Denn nur das entspricht dem Wesen des Gottes Israels, der selbst ein ewig kommender Gott ist" (Marquardt 1998:327). De beelden van de "historische Jezus" als ook van de "Christus der Schriften" zoals die in een concrete preek aan de orde komen, dragen volop de vingerafdrukken van de prediker 
zelf, de gemeente en de culturele context waar deze deel van uitmaken. In het "est" drukt de geloofsgemeenschap haar vertrouwen in het wonder uit dat in en door de menselijke beelden God zelf zich in de komende Christus opent voor de mens opdat de mens zich opent voor Hem. Daarom nodigt dat "est" uit tot gebed, zowel tijdens de voorbereiding door de predikant, door de gemeente tijdens de periode van voorbereiding als ook na afloop van de prediking. Dat "est" weet zich afhankelijk van Gods Geest die in de reformatorische traditie ook wel de "na-prediker" wordt genoemd.

\subsection{Preken als vraag naar de Geest}

Wanneer we de vraag stellen naar de presentie van de Christus in de prediking komen we, zoals gezegd, niet verder met een statische christologie waarin de antwoorden volkomen vast liggen en in de prediking gerepeteerd worden. Anderzijds komen we ook niet verder met een vrijblijvendheid die weigert een oriëntatie te bieden om in de prediking Christus te ontmoeten. Daarom pleiten we voor een homiletische inzet die recht wil doen aan de dynamiek van de christologische vragen. De prediking heeft haar plaats binnen het geheel van een liturgie. De preek staat niet op zichzelf; gebeden, liederen en sacramenten omgeven haar. Een collage van teksten en handelingen vormt de liturgische bedding waarin mensen wachten op het komen van God en de presentie van Christus. Kortom, binnen de ene beweging wordt een andere, die van Gods komen verwacht. We kunnen die twee bewegingen die op elkaar inlopen en inspelen duiden als het communicatieve krachtenveld van de Geest. $\mathrm{Nu}$ is een verwijzing naar de Geest altijd riskant. Te veel is de Geest gebruikt als een alibi om noeste hermeneutische en exegetische preekarbeid en inzichten vanuit de menswetenschappen te weren uit het betoog. Dat kan niet onze bedoeling zijn. Wanneer we hier aandacht vragen voor de Geest doen we dat vanuit de homiletische premisse dat de prediking tenslotte geen antwoorden geeft maar de facto de ruimte uitspaart waarin Christus aanwezig kan komen en zelf zijn woord spreekt, ubi et quando visum est Deo, zoals Barth bij voortduur in zijn "Die Kirchliche Dogmatik" poneert. Wij zijn van mening dat Marquardt in dezelfde richting wijst wanneer Hij de God van Israël met name als een komende God tekent. Dat maakt de menselijke inzet om tot woorden te komen die bestand hebben alleen maar intenser. Het is de Geest die als Creator Spiritus mensen taal en beelden inblaast. We geven een paar lijnen aan die ons van belang lijken.

Allereerst vinden we het wezenlijk dat in het bijbels spreken de Geest Christus exegetiseert in de levens van mensen. We zouden de zogeheten "afscheidsreden" van Jezus uit het evangelie naar Johannes met het accent 
op de Trooster kunnen duiden als een homiletische oriëntatie. De Geest brengt het verhaal aangaande Jezus Christus in beweging in de harten van mensen. In het spreken van Paulus over de Geest komt deze activiteit toegespitst naar voren als het communiceren van de centrale noties van kruis en opstanding.

Vervolgens werkt de Geest niet alleen in het individu maar overspant de eeuwen en werkt dan ook in de cultuur. Daarom staat "het waagstuk van de prediking” in het licht van de humaniteit. De vruchten van de Geest door de eeuwen heen gaan als teken van menselijkheid door mensenlevens heen. In die zin komen ook de verworvenheden van kunst en cultuur in een mild en kritisch licht te staan. Op de derde plaats stelt de Geest het verhaal aangaande Christus present, en wel zo dat in dat verhaal Christus zelf meekomt als de Levende. Dat is voor ons de betekenis van het "est". Daarom is de prediking niet alleen discontinu, niet alleen momentaan, niet alleen de inslag van het Woord Gods, maar ze is ook continu. Zij gaat ook met mensen mee en sterkt het geloof. De beroemde "perseverantia sanctorum" is een bij uitstek pneumatologische categorie en wordt gevoed door de prediking. Wanneer in het verhaal de Levende meekomt is er ook te spreken over de "viva vox evangelii". Zeker, indirect en door de woorden en beelden van mensen heen, maar dan toch. Zouden mensen onder het gehoor nooit eens de ontdekking doen dat zij woorden ontvangen die hun hart zo raken dat zij omkeren? Door de tijden heen klinken er antwoorden op de vraag van Jezus: “Maar gij, wie zegt gij dat ik ben?” In de prediking ontvangen mensen de ruimte om vandaag in de discontinuïteit die deze vraag vooronderstelt, het is een vraag naar een antwoord voorbij de antwoorden, en in de continuïteit die zij belooft, het "Ik" van Christus omvat de tijden, hun antwoord te geven.

\section{RESUMÉ}

Een inzet van de prediking vanuit de erkenning dat de Geest de brug slaat tussen God en mensen, behoedt haar voor verstarring en opent de weg naar gevulde creativiteit. Daarover tot slot enkele samenvattende en concluderende opmerkingen.

1. Wanneer we zeggen dat de prediking een ruimte uitspaart waar Christus zelf het woord kan nemen, dan is dat het einde van een parmantige christologie. In die ruimte bidden predikant en gemeente om Gods Geest opdat deze zelf het Woord neemt. Dit "uitsparen van een ruimte" is iets anders dan de door ons geconstateerde verlegenheid. Dat laatste kan immers ook het gewaad zijn waarin luiheid of ook lafheid zich hult. Wij willen deze ruimte, waar Barth en Marquardt elk op hun eigen manier voor pleiten, 
vanuit inhoudelijke overwegingen bewaken. In deze ruimte kan God zelf het woord nemen - het Woord gesproken in Jezus Christus, een Woord dat telkens geactualiseerd wordt door de Geest daar waar de God van Israël zich als een komende God in het midden van mensen laat kennen.

Deze ruimte dient dan ook fier en ferm te worden behoed tegenover imperialisme en fixatie van welke aard dan ook. Dit leidt niet tot een kleurloos of voorzichtig zwijgen. Het besef van deze ruimte geeft juist aanleiding tot actieve participatie in de beweging van Jezus de Christus. Het nodigt uit tot een intens gebed: Maranatha. Daarbij geldt zowel dat dit engagement de brandstof is voor de hoop als ook het omgekeerde (Marquardt 1998:358, 369).

2. Het bewaken van deze ruimte geschiedt in deemoed. Barth en Marquardt wijzen beiden naar deze grondhouding, zij het dat zij elk vanuit een andere invalshoek spreken en tegen een andere culturele achtergrond theologiseren. Beiden pleiten voor een eerbiedig en voorzichtig spreken aangaande Christus waar geen plaats is voor enige vorm van zelfvoldaanheid, hetzij tegenover de Joden, hetzij tegenover andersdenkende mede-christenen, hetzij tegenover de wereld. Die eerbied en die deemoed achten wij van groot belang voor de prediking. Langs die lijnen pleiten wij voor voorzichtigheid ten opzichte van voorgegeven confessionele of dogmatische terminologie. Dat doen wij niet vanuit een historisch-kritische grondhouding waarbij we niet meer zouden kunnen of mogen zeggen dan historisch te funderen valt maar wij pleiten voor deze deemoed op theologische gronden.

3. Het bewaken van de ruimte geschiedt door getrouw de getuigen aangaande Jezus Christus af te tasten en voortdurend te zoeken naar de verankering daar van in de boeken van Mozes, de profeten en David. Vanuit dat getuigenis komt God in ons midden. Zonder dat dit mechanisch of automatisch werkt, openen gemeente en predikant de Schriften in het vertrouwen dat Hij ons zelf voor zal gaan en dat Hij zelf de ontmoeting zoekt (Math 28:7).

4. Daar moeten we direct aan toevoegen dat dit voor de gemeente betekent dat zij gemandateerd is en opgeroepen wordt om vanuit het getuigenis dat uit de Schriften klinkt, zelf antwoord te geven op de christologische vraag: “wie zeggen jullie dat Ik ben?” Dat antwoord geven mensen in de praktijk van elke dag door zich te engageren met de beweging van Jezus van Nazareth.

\section{Literatuurverwijsen}

Allen, R J 1995. Miracles, in Willimon, W H \& Lischer, R (eds), Concise Encyclopaedia of Preaching, 333- 335. Louisville: Westminster John Knox Press. 
Bakker, N T, Klouwen, W \& Kouwijzer, R Q (reds) 2000. “De noodzaak van de preek”, in de serie Om het levende woord, deel 10, Kampen: Kok.

Barth, K 1922. Der Christ in der Gesellschaft, in Barth, K. Das Wort Gottes und die Theologie, 33- 69. München: Chr. Kaiser Verlag.

-, [1922] 1990a. Das Wort Gottes als Aufgabe der Theologie, in Barth 1990d:144-175.

-, [1922] 1990b Not und Verheissung der christlichen Verkündigung, in Barth 1990d:65-97.

-, [1923] 1990c. Reformierte Lehre, ihr Wesen und ihre Aufgabe, in Barth 1990d:202-247.

-, [1922-1925] 1990d. Vorträge und kleinere Arbeiten 1922-1925, Hrsg von H Finze. Zürich:

Theologischer Verlag. (Gesamtausgabe, III, Vorträge und kleinere Arbeiten).

-, 1940. Die Kirchliche Dogmatik II/1, Zürich: Evangelischer Verlag.

-, 1980. Einführung in die evangelische Theologie (GTS 191), Gütersloh: Gütersloher Verlaghaus.

Bohren, R 1986. Predigtlehre. München: Kaizer. (EETh).

Bond, S L 1999. Trouble with Jesus. Women, Christology and Preaching. St. Louis: Chalice

Press.

Bonhoeffer, D 1989. Verzet en overgave. Baarn: Ten Have.

Bukowski, P 1995. Predigt wahrnehmen. Homiletische Perspektiven. Neukirchen-Vluyn: Neukirchener Verlag.

Buttrick, D 1987. Homiletic. Moves and Structures. Philadelphia: Fortress Press.

Campbell, C L 1997. Preaching Jesus. New Directions for Homiletics in Hans Frei's Postliberal Theology. Grand Rapids: W B Eerdmans.

Cullmann, O 1946. Christus und die Zeit. Die Urchristliche Zeit- und Geschichtsauffassung. Zollikon/Zürich: Evangelischer Verlag.

Cullmann, O 1965. Heil als Geschichte. Heilsgeschichtliche Existenz im Neuen Testament. Tübingen: Mohr.

De Jonge, H J 1989. Ontstaan en ontwikkeling van het geloof in Jezus' opstanding, in Van Gennep, F O \& Zuurmond, R, Waarlijk opgestaan!. Een discussie over de opstanding van Jezus Christus, 31-50. Baarn: Ten Have.

De Jonge, H J 1997. De historisch kritische methode. PT 24, 446.

-, 1998. Eerherstel voor het Koninkrijk, in Deurloo \& De Jonge 1998:9-20.

-, 1998. De plaats van de verzoening in de vroegchristelijke theologie, in Deurloo \& De Jonge 1998:63-90.

Den Heyer, C J 1986. De Messiaanse weg 2 (Jezus van Nazareth), Kampen: Kok.

Deurloo, K A \& De Jonge, H J 1998. Verzoening of Koninkrijk. Over de prioriteit in de verkondiging. Nijkerk: Callenbach.

Drewermann, E 1992. Wenn der Himmel die Erde berührt.Predigten über die Gleichnisse Jesu. Düsseldorf: Patmos.

-, 1993. Und legte inhnen die Hände auf. Predigten über die Wunder Jesu. Düsseldorf: Patmos.

-, 1996. Jesus von Nazareth. Befreiung zum Frieden Bd. 2: Glauben in Freiheit. Zürich/Düsseldorf: Patmos.

Douma, J 2000. Veni Creator Spiritus, De meditatie en het preekproces. Kampen: Kok.

Eickhoff, K 1998. Die Predigt beurteilen. Gemeinde denkt mit. Wuppertal: R Brockhaus Verlag.

Forde, G O 1990. Theology Is for Proclamation. Minneapolis: Fortress Press.

Hahn, F 1963. Christologische Hoheitstitel. Ihre Geschichte im frühen Christentum. Göttingen: Vandenhoeck \& Ruprecht. (FRLANT, 83)

Hoekstra, T 1975. Gereformeerde Homiletiek. Amsterdam: Bolland.

Greidanus, S 1999. Preaching Christ form the Old Testament. A Contemporary Hermeneutical Method. Grand Rapids: W B Eerdmans.

Karelse, L 1999. Dwalen, over Mark C. Taylor en Karl Barth. Zoetermeer: Boekencentrum. 
Klouwen, W 2000. De gemeente onder het woord Gods, in Bakker, N T, Klouwen, W \& Kouwijzer, R Q (49-60). Kampen: Kok.

Kuitert, H M 1998. Jezus: nalatenschap van het christendom. Schets voor een christologie. Baarn: Ten Have.

Lindijer, C H \& Baneke, J J 1992. Jezus ter sprake. Op zoek naar de plaats van Jezus Christus in pastorale praktijk en pastorale psychologie. Zoetermeer: Boekencentrum.

Lindner, W -V 1993. Predigten eines Psychoanalytikers. Göttingen-Zürich: Vandenhoeck und Ruprecht.

Marquardt, F -W 1988. Von Elend und Heimatsuchung der Theologie. Prolegomena zur Dogmatik. Gütersloh: Chr. Kaiser Gütersloher Verlagshaus.

Marquardt, F-W 1998. Das christliche Bekenntnis zu Jesus dem Juden. Eine Christologie (Band 2). Gütersloh: Chr. Kaiser Gütersloher Verlagshaus.

Miskotte, K H 1971. Het jodendom als vraag aan de kerk, in Miskotte, K H, Om de waarheid te zeggen. Opstellen over het kerkelijk belijden, 185-193. Kampen: Kok.

Resner, A 1999. Preacher and Cross. Person and Message in Theology and Rhetoric. Grand Rapids: W B Eerdmans.

Samen-op-Weg kerken 2001. Jezus Christus, onze Heer en Verlosser. Zoetermeer:

Boekencentrum.

Sanders, E P 1993. The Historical Figure of Jesus. London: Penguin.

Schmidt, P 2000. In de handen van mensen, 2000 jaar Christus in kunst en cultuur. Kampen/Leuven: Davidsfonds/Kok.

Smit, J \& Stroeken, H 1993. Lotgevallen. De bijbel in psychoanalytische perspectief. Amsterdam: Boom.

Sobrino, J 1978. Christology at the Crossroads. A Latin American Approach. London: SMC Press.

Stolp, H 1998. Jezus van Nazareth. Esoterisch bijbellezen. Deventer: ANKH Hermes.

Ter Linden, N M A 1998. Het verhaal gaat ... 2 (Het verhaal van Marcus en het verhaal van Mattheüs. Amsterdam: Balans.

Troeger, T 1999. Preaching While the Church is under Reconstruction. The Visionary Role of Preachers in a Fragmented World. Nashville: Abingdon.

Van de Beek, A 1998. De Christologie als hart van de theologie. Kampen: Kok.

Van der Kooi, C 1985. De denkweg van de jonge Karl Barth. Amsterdam: V U Uitgeverij.

Van Knippenberg, T 1998. 'De pastor als theoloog'. Praktische Theologie 3, 191-205.

Wissink, J 1983. De inzet van de theologie, Een onderzoek naar de motieven en geldigheid van Karl Barths strijd tegen de natuurlijke theologie. Amersfoort: De Horstink. 